\title{
Protein CASC4
}

National Cancer Institute

\section{Source}

National Cancer Institute. Protein CASC4. NCI Thesaurus. Code C131616.

Protein CASC4 (433 aa, $49 \mathrm{kDa}$ ) is encoded by the human CASC4 gene. This protein may play a role in protein maturation and tumorigenesis. 